\title{
Use of Topical Landmarks for Percutaneous Projection of Intracranial Tumors for Neurosurgical Oncology
}

\author{
Nöroonkolojik Cerrabide Intrakranial Tümörlerin Topikal Işaretler \\ Kullanularak Perkütan Projeksiyonu
}

\author{
Keramettin AYDIN ${ }^{1}$, Ersoy KOCABICAK ${ }^{1}$, Adnan ALTUN ${ }^{1}$, Ilkay OZAYDIN², Ercan YARAR ${ }^{1}$, Cengiz COKLUK ${ }^{1}$ \\ ${ }^{1}$ Ondokuz Mayis University, Faculty of Medicine, Department of Neurosurgery, Samsun, Turkey \\ ${ }^{2}$ Ondokuz Mayis University, Faculty of Medicine, Department of Radiology, Samsun, Turkey
}

Correspondence address: Ersoy KOCABICAK / E-mail: ekocabicak@yahoo.com

\begin{abstract}
AIM: The objective of this study was to introduce a surgical navigation method which provides a safe, quick and effective access to cortical and subcortical tumors, along with a review of other methods in use for this purpose.

MATERIAL and METHODS: 53 patients have been operated using this technique. The area overlying the tumor is shaved and one half of a smoothly cut hazelnut is taped on the skin. The precise localization of the hazelnut is confirmed with MRI and then stained. After general anesthesia, the stained impression is projected firstly to the bone, dura and then cortex respectively by the Midas Rex cutting tip. Cortical landmarks surrounding the tumor's cortical projection are further confirmed with ultrasonography.

RESULTS: After removal, cortical and subcortical tumors were separately graded for efficiency. Grade 1 and 2 were accepted as precise access. Our method accordingly yielded $95.2 \%$ and $90.6 \%$ success rates for cortical and subcortical tumors respectively.

CONCLUSION: Considering the method's success rate along with its inexpensiveness and modest technical requirements, it is believed that this method can be of widespread use.
\end{abstract}

KEYWORDS: Cortical landmarks, Subcortical tumor, Cortical tumor, Tumor localization, Surgical navigation

ÖZ

AMAÇ: Bu çalışmanın amacı, kullanımda olan diğer metodları da gözden geçirerek, topikal işaretler yardımıyla kortikal ve subkortikal yerleşimli tümörlerde etkili, güvenli ve hızlı bir cerrahi yöntemi sunmaktır.

YÖNTEM ve GEREÇLER: 53 hasta bu teknik kullanılarak opere edildi. Tümörün izdüşümündeki saçlı deri traş edildikten sonra düzgün şekilde yarısı kesilmiş fındık cilt üzerine yapıştıııldı. Fındığın tümör izdüşümündeki lokalizasyonu doğrulandıktan sonra alan işaretlendi. Genel anestezi altında işaretlenmiş alanın izdüşümü alınarak sırasıyla kemik ve dura, kortekse kadar Midas rex kesici uç yardımıyla işaretlendi. Tümör ve onu çevreleyen kortikal yapılar ultrasonografi yardımıyla görüldü ve doğrulandı.

BULGULAR: Tümör çıkartıldıktan sonra etkinlik açısından derecelendirme yapıldı. Buna göre grade 1 ve grade 2 lokalizasyon açısından kesin doğru giriş noktası olarak kabul edildi. Bizim metodumuzun subkortikal tümörlerde $\% 90,6$ ve kortikal tümörlerde $\% 95,2$ oranında giriş noktası açısından etkin olduğu saptandı.

SONUÇ: Bu yöntem ucuzluğu, basit ve kolay şekilde uygulanabilirliği nedeniyle geniş bir kullanım alanı olabilecek bir teknik gibi gözükmektedir. ANAHTAR SÖZCÜKLER: Kortikal landmarklar, Subkortikal tümör, Kortikal tümör, Tümör lokalizasyonu, Cerrahi navigasyon

\section{INTRODUCTION}

Cortical damage infliction during intracranial cortical and subcortical tumor surgery can lead to irreversible function loss. These motor and sensory deficits have deleterious effects on the patients' quality of life. Therefore, keeping collateral cortical damage at minimum during intracranial tumor ablation is of vital importance. The neocortical surface is formed by a complex interlace of sulci and gyri that not only house critical neural networks, but are also crucial for surgical navigation as well. Using MRI (Magnetic Resonance
Imaging), cortical landmarks such as sulci, gyri and vessels can be defined, along with the tumor and its neighboring structures $(1,28)$. Cortical and vascular structures surrounding the tumor, which are best visualized, after the administration of the contrast medium, are useful for planning the surgery as well $(11,15,16,29)$. For example, a cortical vein is very useful for pinpointing the lesion while avoiding venous bleeding. The choice of craniotomy significantly influences the incidence of postoperative neurological deficits (9). Many imaging modalities including functional MRI have been developed 
in order to define cerebral cortical anatomy in intracranial tumors with cortical involvement $(12,23)$. Recent studies have demonstrated that functional MRI more effectively visualizes focal brain neoplasias and their relations to the sensorial and motor cortex (9).

A number of MRI-utilizing modalities have been developed to safely navigate through the cortex to access cortical and subcortical tumors. In this paper, we are introducing a simple, inexpensive and highly effective method for planning skin incision, craniotomy flap and excision margins for cortical and subcortical tumors using the MRI-assisted tumor projection method.

\section{PATIENTS/MATERIAL and METHODS}

Fifty-three patients with cortical and subcortical tumors treated in our clinic between years 2006 and 2010 were included in our study. The tumors were located in the parietal lobe in 43 and frontal lobe in 10 of the patients. The pathological studies revealed that they consisted of meningiomas (24), brain metastases (26), cavernomas (1) and primary brain tumors (17). These patients were divided into two categories depending on the cortical and subcortical localization of the tumor ( $39.6 \%$ and $60.4 \%$, respectively). The surgical outcomes of the patients were graded according to the precision of tumor excision.

Imaging: A $3 \times 3 \mathrm{~cm}$ area which approximately overlies the tumor on the patients' hair is shaved with a clipper, and one half of a smoothly cut hazelnut is taped on the skin. After that, the patient accompanied with a neurosurgeon is sent to $\mathrm{MRI}$ and $0.1 \mathrm{mmol} / \mathrm{kg}$ contrast material is administered (Magnevist ${ }^{\circledR}, 0,5 \mathrm{mmol} / \mathrm{mL}$, Schering, Germany). After the first $\mathrm{MRI}$, the localization of the hazelnut is checked and adjusted until it is located precisely over the tumor's projection in axial, coronal and sagittal plains confirmed with imaging following each adjustment. After the localization of the hazelnut is confirmed, its underside is painted with a skin marker and returned to its localization. Then contrast-enhanced T1weighted axial and coronal images are obtained (Tesla active super-conducting magnet system, Magnetom SymphonyQuantum, Siemens, Erlangen, Germany) (Figure 1A,B). The hazelnut is firmly kept in place until surgery.

Surgical Technique: Under general anesthesia, the patients' head is fixed with a Mayfield skull clamp. The hazelnut is removed and the staining on the skin is checked (Figure 2). After prepping and draping, the stained impression is projected to the bone using the Midas Rex cutting tip (Figure 3). Once the consistency of bone is felt, the skin flap is raised. The impression made by the cutting tip is located and it is drilled past to dura. The dura is marked with a marker past the initial drill hole and a $4 \times 4 \mathrm{~cm}$ craniotomy is made (Figure $4 A, B)$. The marked spot on the dura is located and the cortex is likewise marked through a small incision. The dura is then duly incised to expose the cortex (Figures 5, 6). A cortical tumor is directly removed after this exposure. For a subcortical tumor, the cortical landmarks which have been visualized previously
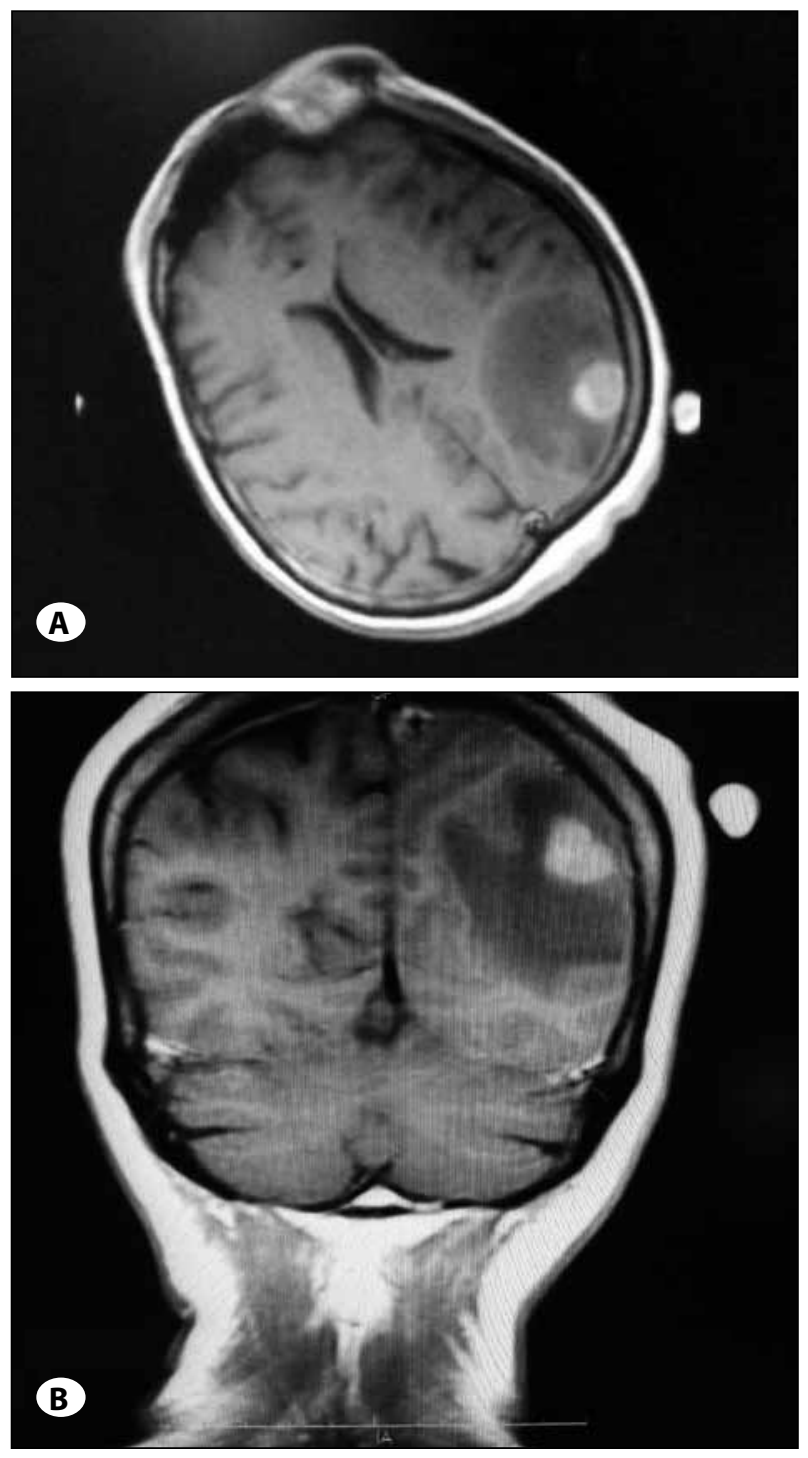

Figure 1: A) T1-weighted contrasted axial section MRI with hazelnut on the skin. B) T1 weighted contrasted coronal section MRI with hazelnut on the skin.

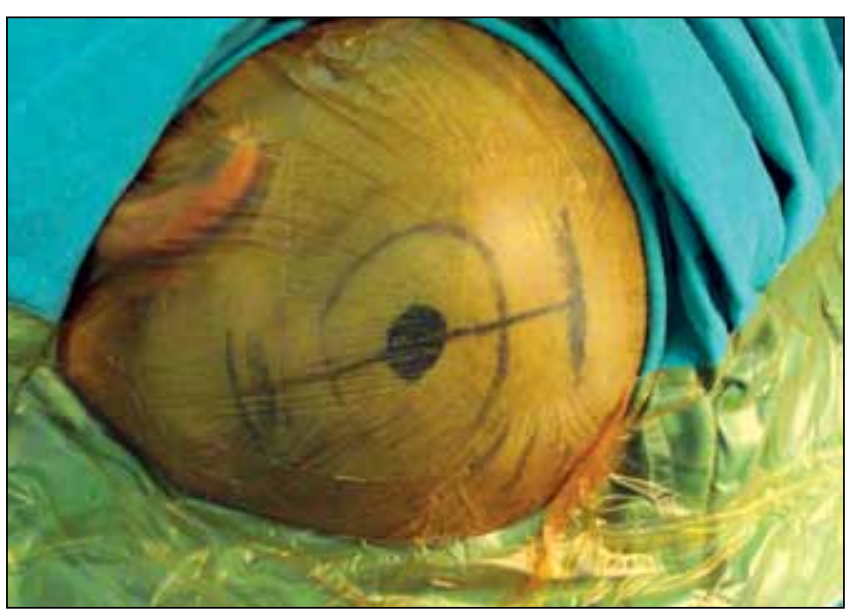

Figure 2: The patient's head is fixed with Mayfield skull clamp, the hazelnut is removed and the staining on the skin is checked. 


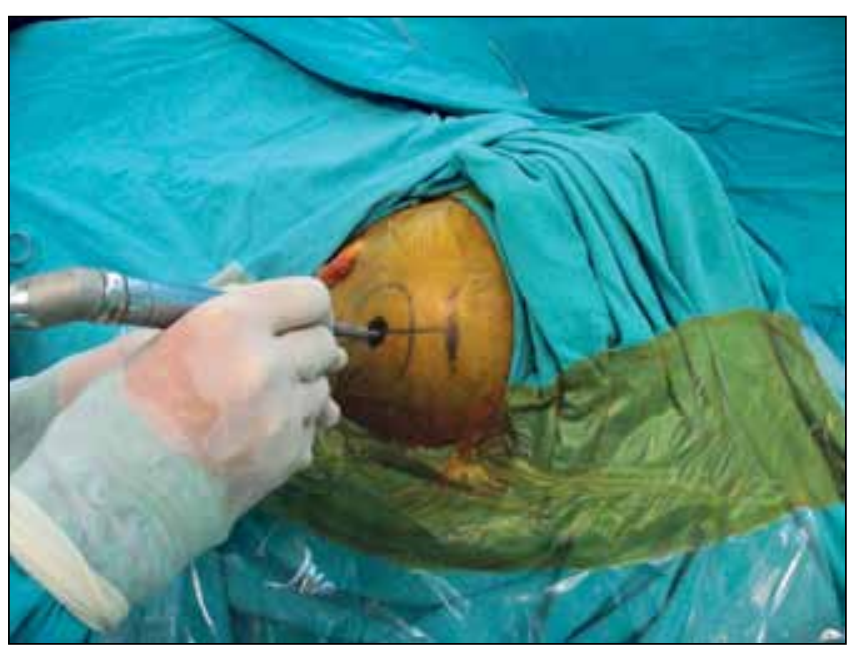

Figure 3: After prepping and draping, the stained impression is projected to the bone using the Midas Rex cutting tip.
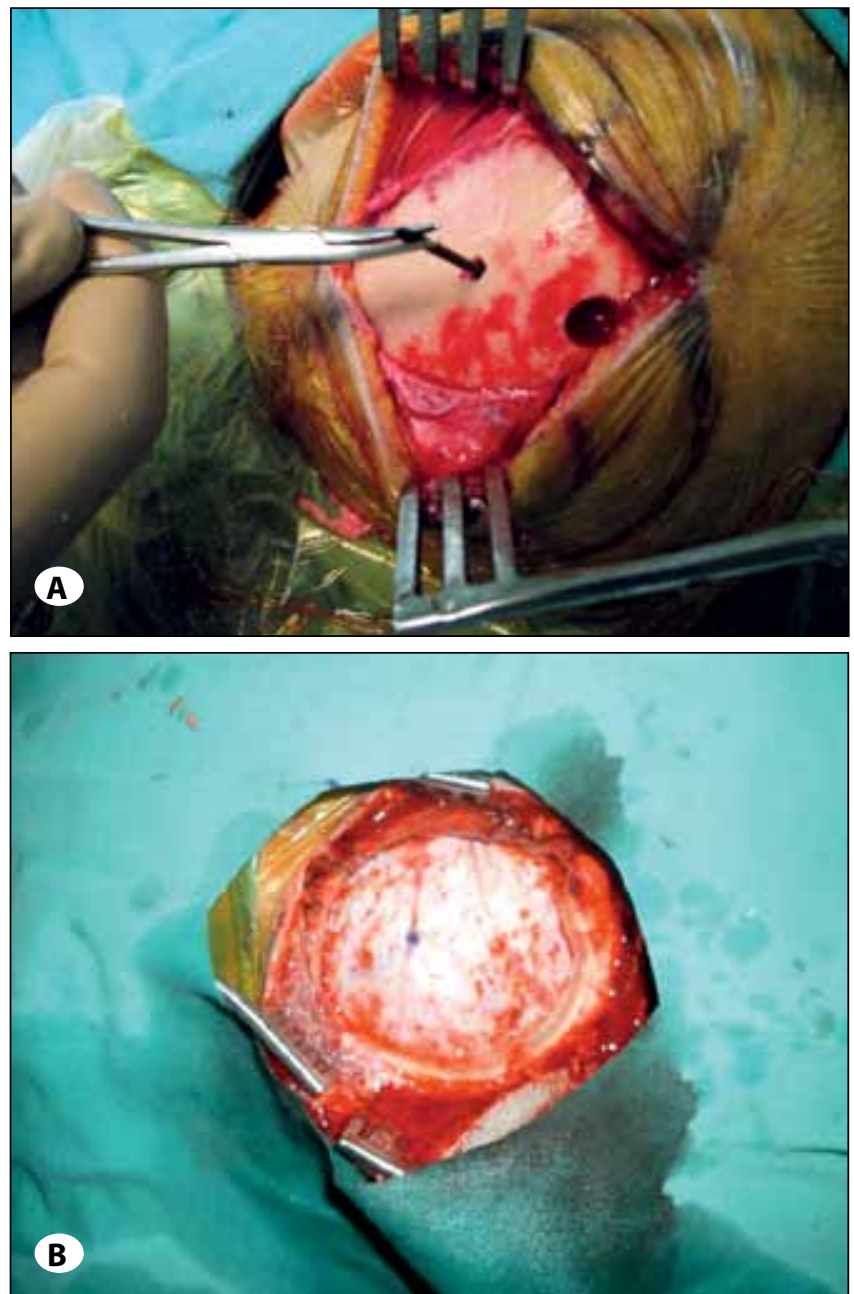

Figure 4: A) The appearance of exposed calvarial surface with the impression made by the Midas Rex cutting tip. B) After the calvarial flap has been raised, the dura is seen with the impression of the cutting tip.

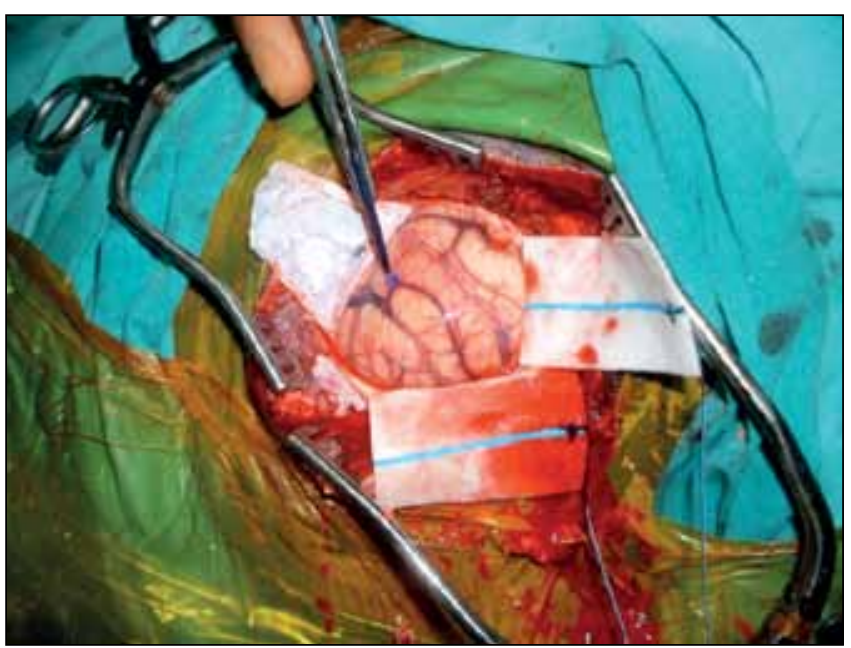

Figure 5: Cortical surface. The instrument tip points to the impression of the cutting tip, which the tumor lies directly underneath.

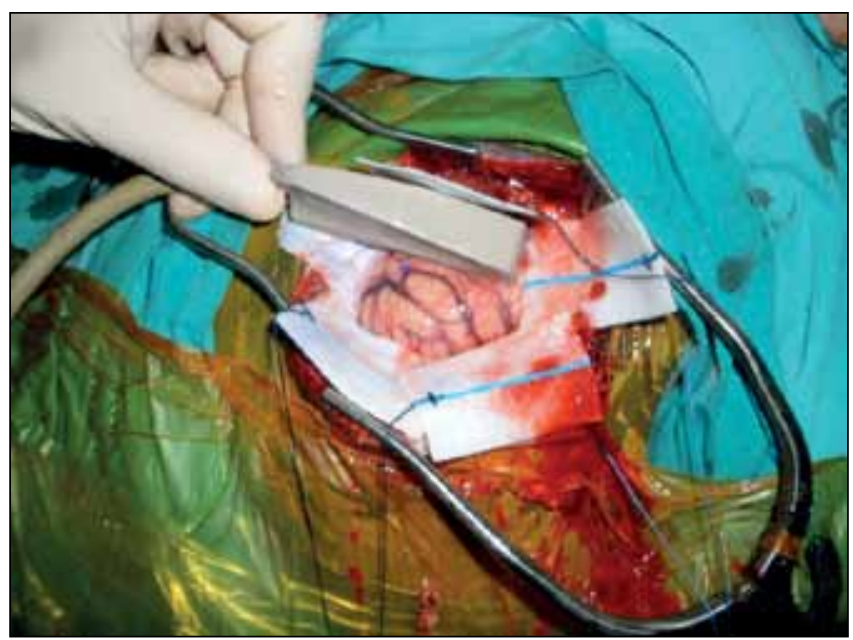

Figure 6: Surface USG to confirm the tumor presence underneath the projection.

are utilized and three-dimensional volume-rendered MR images are compared with real-time appearance. Cortical landmarks surrounding the tumor's cortical projection are further confirmed with cortical ultrasonography (USG). The cortical split is then done accordingly. Thus, the exact relationship between the central sulcus and the split is known and the tumor is removed without damaging the superficial veins or inflicting redundant cortical damage. All patients undergo contrast-enhanced MRI within the first 2 postoperative days (Figure 7A,B).

\section{RESULTS}

The efficacy of the method has been evaluated via a grading system. Grading in cortical tumors was done according to the projection's accuracy in covering the boundaries of the tumor. Grading of subcortical tumors were done according to the match between the previously made projection and the cortical projection of the tumor which was perioperatively 

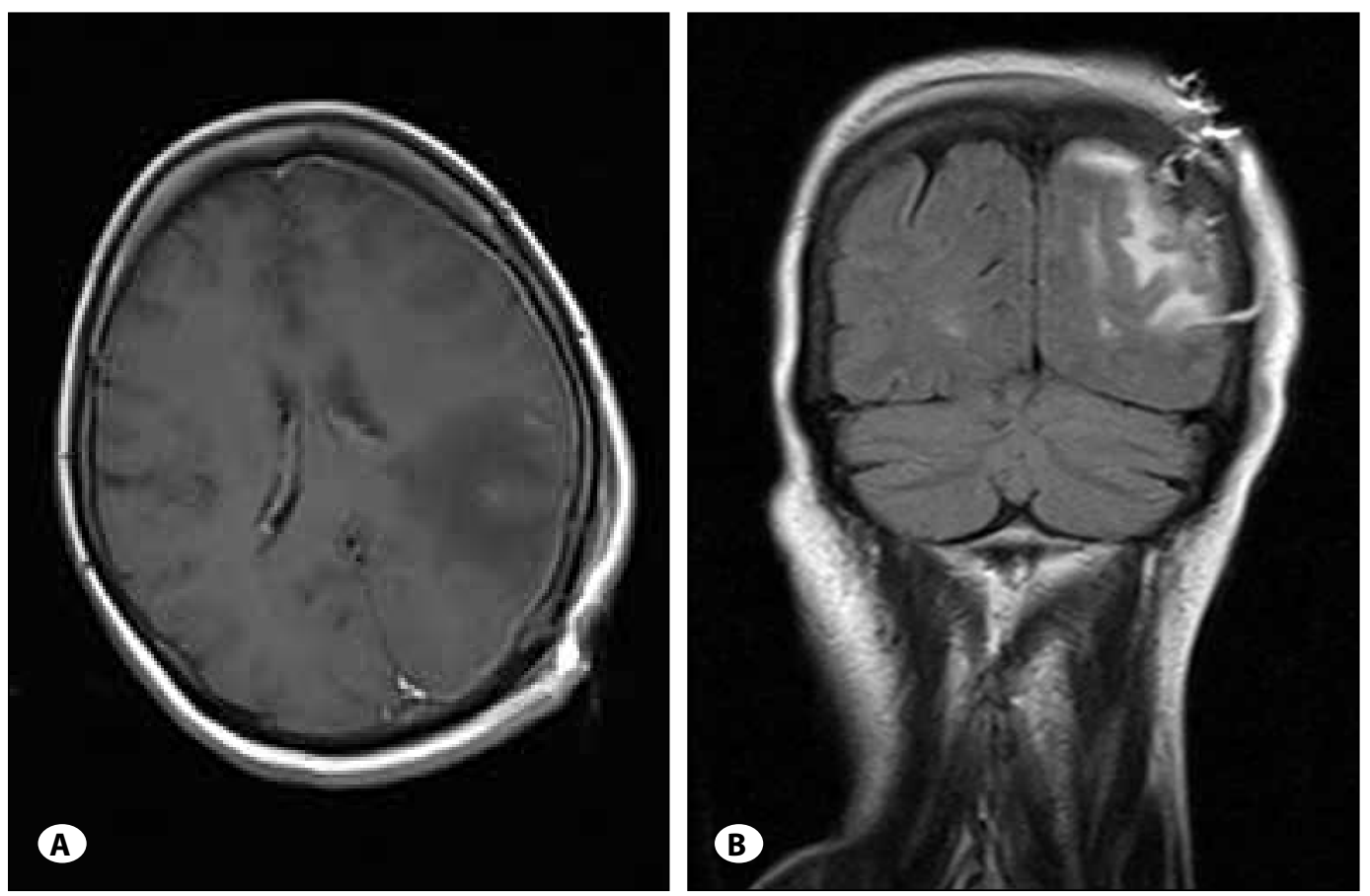

Figure 7:

A) Postoperative T1weighted contrasted axial section MRI

B) Postoperative T1weighted contrasted coronal section MRI.

established by USG. Grade 1 and 2 are considered successful. In the follow-up of our patients, the postoperative complication rate was $12.5 \%$ in the subcortical tumor category (4 patients). Within the cortical tumor group, only 1 patient developed a mild motor deficit which resolved spontaneously $(4.7 \%)$ (Table I).

\section{DISCUSSION}

Total surgical ablation of the tumor has been considered the ultimate treatment in a brain neoplasia $(5,7,14,22)$. However, damaging the cortical substance along the way may have catastrophic consequences. The precise tumor localization is of vital importance especially when the tumor is virtually indistinguishable from the surrounding intact tissue.

The stakes of technological developments are increasing day by day in this field. Image-guided neurosurgical techniques using navigation systems have been used in patients with brain tumors since 1980's (27). Utilization of these developments provided more accurate access to the tumor, which was reflected in decreased morbidity, shorter hospitalization and lower cost $(2,19)$.

Frameless image-guided navigation systems are widely used in intracranial surgery (19). Anatomic deformation of the parenchyma can effectively be demonstrated intraoperatively by integration of Computerized Tomography (CT) and MRI data to the navigation system (17). However, its cost and requirement for trained staff have limited its use (6). The use of this system also requires extensive intraoperative time $(6,10)$.

These drawbacks called for a simple method with more modest requirements. Subcortical brain tumors cannot be distinguished from the brain's surface even after considerable growth in size (8). Intraoperative USG and MRI can pinpoint these lesions following cortical exposure but require time under general anesthesia, are costly and their accuracies are compromised due to brain shift $(20,26)$. Real time navigation systems such as intraoperative MRI and three-dimensional USG are very effective diagnostic tools but require special and expensive hardware (13).

MRI-based corticotopography developed by Esposito et al. has been successfully used for intraoperative localization of subcortical brain tumors. However, it is more complex and expensive than our method and it depends on external landmarks such as craniometric points, mastoid bone and the external ear for bone flap planning (8).

Surgical planning is done according to the cortical landmarks

Table I: Grading the Success of the Projections in the Operated Patients. Grade 1: Projection Exactly Matches the Actual Tumor. Grade 2: The Margin of Error Between the Projection and the Tumor is Less than $5 \mathrm{~mm}$. Grade 3: The Margin of Error Between the Projection and the Tumor is Greater than $5 \mathrm{~mm}$

\begin{tabular}{l|c|c} 
& Cortical Tumor $(\mathbf{n = 2 1 )}$ & Subcortical Tumor $(\mathbf{n = 3 2 )}$ \\
\hline Grade 1 & $16(76,2 \%)$ & $21(65,6 \%)$ \\
Grade 2 & $4(19 \%)$ & $8(25 \%)$ \\
Grade 3 & $1(4,7 \%)$ & $3(9,3 \%)$
\end{tabular}


and thus preserves our orientation in our system. The system uses the sulci, gyri and vessels in the vicinity of the tumor and thus provides the surgeon extensive comfort while accessing the cortical tumors. While this method can likewise be used for subcortical tumors, an intraoperative USG is recommended for confirming the location of the tumor before commencing the cortical split. The system therefore provides quick access to the tumor with minimal cortical split.

Three-Dimensional Volume Rendering for Tissues (3D VRT) has been utilized for surgical planning in our clinic since 2002 . We have achieved $80 \%$ correlation with 3D VRT images and surgical observation. Easier skin incision planning and smaller bone flap requirement have been achieved via the projection method. This method provides smaller chances of encountering unpleasant surprises in the postoperative period along with better orientation for the surgeon. The rate of postoperative deficit following subcortical tumor ablation in our series has been $12.5 \%$, which is comparable with the $13-27.5 \%$ postoperative deficit rates reported in the literature $(3,4,21,25)$. The only postoperative complication encountered in cortical tumor ablation in our series has been a transient motor deficit which spontaneously resolved.

\section{CONCLUSION}

We believe that we are introducing a cost effective, convenient and reliable method for swiftly and accurately accessing cortical and subcortical tumors.

\section{REFERENCES}

1. Aydin K, Cokluk C, Kuruoglu E , Gelmez S, Diren B, Rakunt C, Celik F: Using the magnetic resonance three-dimensional volume rendering for tissues.Minim Invas Neurosurg 49 (4): 189-193, 2006

2. Barnett $G H$, Kormos DW, Steiner $C P$, Weisenberger J: Use of Frameless, armless stereotactic wand for brain tumor localization with two-dimensional and three-dimensional neuroimaging. Neurosurgery 33: 674-678,1993

3. Brell M, Ibanez J, Caral L, Ferrer E: Factors influencing surgical complications of intra-axial brain tumors. Acta Neurochir 142:739-750, 2000

4. Cedzich C, Taniguchi M, Schafer S, Schramm J: Somatosensory evoked potential phase-reversal and direct motor cortex stimulation during surgery in and around the central region. Technical application. Neurosurgery 38: 962-971,1996

5. Claus EB, Horlacher A, Hsu L, Schwartz RB, Dello-lacono D, Talos F, Jolesz FA, Black PM: Survival rates in patients with lowgrade glioma after intraoperative magnetic resonance image guidance. Cancer 103:1227-1233, 2005

6. Comeau RM, Sadikot AF, Fenster A, Peters TM: Intraoperative ultrasound for guidance and tissue shift correction in imageguided neurosurgery. Med Phys 27:787-800,2000

7. Duffau H: Contribution of cortical and subcortical electro stimulation in brain glioma surgery: Methodological and functional considerations. Neurophysiology Clinique/Clinical Neurophysiology 37: 373-382, 2007
8. Esposito V, Paolini S, Morace R, Colonnese C, Venditti E, Calistri V, Cantore G: Intraoperative localization of subcortical brain lesions. Acta Neurochir 150: 537-543, 2008

9. F. Z. Yetkin, Papke RA, Mark LP, Daniels DL, Mueller WM, Haughton VM: Haughton location of the sensorimotor cortex: Functional and conventional MR compared. AJNR Am J Neuroradiol 16: 2109-2113,1995

10. Gronningsaeter A, Kleven A, Ommedal S, Aarseth TE, Lie T, Lindseth F, Lango T, Unsgard G: Sono -wand, and ultrasoundbased neuronavigation system. Neurosurgery 47:1373-1380, 2000

11. Jung HW, Chang KH, Choi DS, Han MH, Han MC: Contrast-enhanced MR angiography for the diagnosis of intracranial vascular disease: Optimal dose of gadopentetate dimeglumine. AJR Am J Roentgenol 165:1251-1255,1995

12. Katada K: MR imaging of brain surface structures: surface anatomy scanning (SAS). Neuroradiology 32: 439-448,1990

13. Keles GE: Intracranial neuronavigation with intraoperative magnetic resonance imaging. Curr Opin Neurol 17:497-500, 2004

14. Keles GE, Lamborn KR, Berger MS: Low-grade hemispheric gliomas in adults: A critical review of extent of resection as a factor influencing outcome. J Neurosurg 95:735-745, 2001

15. Kirchhof K, Welzel T, Jansen O, Sartor K: More reliable noninvasive visualization of the cerebral veins and dural sinuses: Comparison of three MR angiographic techniques. Radiology 224: 804-810, 2002

16. Liang L, Korogi $Y$, Sugahara T, Onomichi M, Shigematsu $Y$, Yang D, Kitajima M, Hiai Y, Takahashi M: Evaluation of the intracranial dural sinuses with a 3D contrast-enhanced MPRAGE sequence: Prospective comparison with 2D-TOF MR venography and digital subtraction angiography. AJNR Am J Neuroradiol 22: 481-492, 2001

17. Martin AJ, Hall WA, Liu H, Pozza CH, Michel E, Casey SO, Maxwell RE, Truwit CL: Brain tumor resection; intraoperative monitoring with High-field-strength MR imaging-initial results. Radiology 215:221-228, 2000

18. Nimsky C, Fujita A, Ganslandt O, Von Keller B, Fahlbusch R: Volumetric assessment of glioma removal by intraoperative high field magnetic resonance imaging. Neurosurgery 55: 358-370, 2004

19. Ohue S, Kumon Y, Nagato S, Kohno S, Harada H, Nakagawa K, Kikuchi K, Miki H, Ohnishi T: Evaluation of intraoperative brain shift using an ultrasound-linked navigation system for brain tumor surgery. Neurol Med Chir 50(4):291-300, 2010

20. Roberts DW, Haotov A, Kennedy FE, Miga MI, Paulsen KD: Intraoperative brain shift and deformation; a quantiative analysis of cortical displacement in 28 case. Neurosurgery 43 : 749-758,1998

21. Sawaya R, Hammoud M, Schoppa D, Hess KR, Wu SZ, Shi WM, Wildrick DM: Neurological outcomes in a modern series of 400 craniotomies for treatment of parenchymal tumors. Neurosurgery 42:1044-1056,1998 
22. Stummer W, Pichlmeier U, Meinel T, Wiestler OD, Zanella F, Reulen HJ: ALA-Glioma Study Group: Fluorescence-guided surgery with 5-aminolevulinic acid for resection of malignant glioma: A randomised controlled multicenter phase III trial. Lancet Oncol 7:392-401, 2006

23. Tsuchiya K, Katase S, Hachiya J, Hiyama T, Shiokawa Y: A new technique of surface anatomy MR scanning of the brain: Its application to scalp incision planning. AJNR Am J Neuroradiol 20(3):515-518, 1999

24. Unsgaard G, Ommedal S, Muller T, Gronningsaeter A, Nagelhus Hernes TA: Neuronavigation by intraoperative three-dimensional ultrasound: Initial experience during brain tumor resection. Neurosurgery 50: 804-812, 2002

25. Vives KP, Piepmeier JM: Complications and expected outcome of glioma surgery. J Neurooncol 42: 289-302,1999
26. Wadley J, Dorward N, Kitchen N, Thomas D: Pre-operative planing and intr-operative guidance in modern neurosurgery; a reviev of 300 cases. Annu R Coll Surgery Engl 81:217-225, 1999

27. Watanabe E, Watanabe T, Manaka S, Mayanagi Y, Takakura K: Three-dimensional digitizer (neuronavigator); new equipment for computed tomography-guided stereotaxic surgery. Surg Neurol 27:543-547,1987

28. Yang F, Kruggel F: Automatic segmentation of human brain sulci. Med Image Anal 12(4): 442-451, 2008

29. Yang J, Hill M, Morrish W, Hudon ME, Barber PA, Demchuk AM, Sevick RJ, Frayne R: Comparison of pre- and post contrast 3D time-of-flight MR angiography for the evaluation of distal intracranial branch occlusions in acute ischemic stroke. AJNR Am J Neuroradiol 23: 557-567, 2002 